\title{
ANALYSIS OF BONE “COLLAGEN” EXTRACTION PRODUCTS FOR RADIOCARBON DATING
}

\author{
F Brock $^{1,2}$ • V Geoghegan ${ }^{3}$ • B Thomas ${ }^{3}$ K Jurkschat $^{4}$ • T F G Higham ${ }^{1}$
}

ABSTRACT. Archaeological bones are now routinely dated in many radiocarbon laboratories through the extraction of "collagen." Methods for "collagen” extraction vary, and several laboratories now apply an ultrafiltration step after gelatinization to extract the higher molecular weight (usually $>10$ or $30 \mathrm{kDa}$ ) fraction for dating, thereby removing low molecular weight contaminants. Ultrafiltration has been demonstrated to result in products that are easier to handle and have more acceptable $\mathrm{C}: \mathrm{N}$ ratios, and in some instances can result in significantly improved (generally older) ${ }^{14} \mathrm{C}$ dates when compared to non-ultrafiltered products from the same bone. Although it has been suggested that ultrafiltration removes potential contaminants such as short-chain degraded collagen and other peptides and amino acids, fulvic acids, and salts, there remains little published evidence to support this. This paper presents data from a pilot study investigating the most suitable techniques with which to study the products of the routine "collagen" extraction procedures employed at the Oxford Radiocarbon Accelerator Unit (ORAU) (modified Longin followed by ultrafiltration). The preliminary data demonstrates that the final product of "collagen" extraction at ORAU appears to be an aggregate consisting of a range of proteins of different molecular weights, including collagen, as well as some other organic matter and inorganic species. Ultrafiltration is removing some, but not all, of the $<30 \mathrm{kDa}$ fraction from the samples. Further work to investigate the nature of this aggregate and how best to improve the efficiency of “collagen” extraction procedures is discussed.

\section{INTRODUCTION}

Bone is one of the most widely used materials for dating archaeological events, as specimens can directly date the event or period of study and can also provide additional information relating to species, paleodiet (via stable isotopic values), and evidence of anthropological interventions (e.g. cutmarks, etc). Bone consists of $\sim 75-80 \%$ mineral (hydroxyapatite) and $\sim 20 \%$ organic (proteinaceous) material. Approximately $85-90 \%$ of the organic component is type I collagen (Termine 1984), with the remainder being made up of non-collagenous proteins (NCPs), predominantly osteocalcin (also known as Gla protein), but also including osteonectin, glycoproteins, and blood proteins such as serum albumin (Gillespie 1989). Collagen molecules consist of 3 peptide chains ( $2 \alpha-1$ chains hydrogen-bonded to a third $\alpha-2$ chain with a different amino acid sequence), entwined in a helical coil. Although attempts have been made to date both the inorganic phase of bone and osteocalcin (see Hedges and van Klinken 1992 for a review), the most commonly dated fraction is collagen. It should be noted, though, that although often referred to as "collagen," several authors more correctly use the term "gelatin" or "protein remnants" (e.g. Brown et al. 1988) to describe the material extracted from bone, while others have followed the example of DeNiro and Weiner (1988) in using the term "collagen" to refer to extracted degraded archaeological material that has undergone diagenetic alteration.

The mineral and organic phases of bone have a complex structural relationship, and it is believed that the mineral matrix protects collagen from degradation in the burial environment, resulting in the preservation of bone over many hundreds and thousands of years under certain environmental conditions. However, during this time bones can undergo significant diagenetic alterations when collagen can degrade, potentially undergoing hydrolysis with preferential loss of some amino acids or

\footnotetext{
${ }^{1}$ Oxford Radiocarbon Accelerator Unit, Research Laboratory for Archaeology \& the History of Art, University of Oxford, Dyson Perrins Building, South Parks Road, Oxford OX1 3QY, United Kingdom.

${ }^{2}$ Corresponding author. Email: fiona.brock@rlaha.ox.ac.uk.

${ }^{3}$ Sir William Dunn School of Pathology, University of Oxford, South Parks Road, Oxford OX1 3RE, United Kingdom.

${ }^{4}$ Department of Materials, University of Oxford, Begbroke Science Park, Begbroke Hill, Oxford OX5 1PF, United Kingdom.
}

(C) 2013 by the Arizona Board of Regents on behalf of the University of Arizona

Proceedings of the 21st International Radiocarbon Conference edited by A J T Jull \& C Hatté

RADIOCARBON, Vol 55, Nr 2-3, 2013, p 445-463 


\section{F Brock et al.}

humification of parts of the molecule, or when exogenous materials (including humic substances and carbohydrates) randomly cross-link to the original organics (e.g. Gillespie 1989; Hedges and van Klinken 1992; van Klinken 1999). The processes involved in bone diagenesis are complex and still poorly understood (e.g. Hedges and Law 1989; Collins et al. 1995, 2002).

Diagenetic alterations to collagen, as well as the potential presence of contaminants (both from the depositional environment and those applied subsequently during curation and conservation), combine to make the pretreatment of bone prior to radiocarbon dating a complicated procedure. Contaminants can be difficult to identify and remove, and, if not removed properly, their presence can result in erroneous dates if they are of a differing age to the bone itself. Pretreatment prior to dating therefore requires a balance between ensuring contamination is effectively removed, without the addition of any laboratory-derived carbon during the process.

Methods to extract "collagen" from bone for dating vary, but many laboratories use a method based on that of Longin (1971), consisting of an acid demineralization step followed by denaturation in weak acid (gelatinization). The gelatinization irreversibly hydrolyzes the collagen, causing the collagen triple helix to unravel to gelatin, with the aim of eliminating high molecular weight humic substances and other contaminants (e.g. insoluble soil-derived humins) in the process. Dissolution of collagen is not an entirely selective process (van Klinken and Mook 1990 and references therein), and the composition and yield of the final product will depend on the conditions (specifically, temperature, strength and amount of acid, length of time) used when decalcifying and gelatinizing as well as the degree of diagenetic change of the bone. Brown et al. (1988) identified $58{ }^{\circ} \mathrm{C}$ as the optimum temperature for gelatinization at $\mathrm{pH} 3$ (as the fibril structure of mammalian collagen denatures at $\sim 58{ }^{\circ} \mathrm{C}$; Piez 1984). Above this temperature, they observed a constant product yield, but noted a decrease in the proportion of larger proteins with increasing temperature. Semal and Orban (1995) proposed a higher temperature $\left(95^{\circ} \mathrm{C}\right)$ and more acidic conditions $(0.2 \mathrm{M} \mathrm{HCl}$ i.e. $\sim \mathrm{pH} 1)$. Although more drastic than Brown et al.'s (1998) method, Semal and Orban (1995) observed complete collagen solubilization without major degradation in large collagen peptides.

Some ${ }^{14} \mathrm{C}$ laboratories (including ORAU; Brock et al. 2010) have added a base wash to the Longin method to remove humic substances after the initial demineralization step (first proposed by Arslanov and Svezhentsev 1993), although this can result in high sample loss in poorly preserved bones. It has also been reported that a base wash is insufficient to remove all humics from some bones, and that the application of XAD-2 resin is more effective at removing humics without destroying samples (Yuan et al. 2000).

Brown et al. (1988) first proposed the addition of an ultrafiltration step after gelatinization to isolate high molecular weight components of gelatinized "collagen.” Ultrafilters have a molecular weight cut-off, although this is generally accepted to be a broad transitional range, rather than a specific, distinct cut-off (Burba et al. 1995). Hüls et al. (2009), for example, observed differing yields for the same modern and fossil collagen samples when ultrafiltered with 2 different filter types, both with 30kDa molecular weight cut-offs. Brown et al. (1988) hypothesized that contaminants within bone are likely to be of low molecular weight. By using ultrafilters to concentrate the larger peptides, they observed that the extracted "collagen" was lighter in color (which they suggested might indicate removal of some humics) and essentially non-hygroscopic (unlike the fraction removed by the ultrafilters), and that dates on $>30 \mathrm{kDa}$ fractions from several bones were generally older than the associated $<30 \mathrm{kDa}$ fractions.

Ultrafiltration was first added to the routine bone pretreatment procedure applied at ORAU in 2000 (Bronk Ramsey et al. 2000), and was found to result in improved C:N ratios of collagen (generally 


\section{Bone “Collagen” Extraction Products for ${ }^{14} \mathrm{C}$ Dating}

acknowledged to be acceptable between 2.9-3.5; Ambrose 1990) and products that were easier to handle, presumed to be due to the removal of salts (Bronk Ramsey et al. 2004). It has also been observed that ultrafiltration can result in less variation in both C:N ratios and $\delta^{13} \mathrm{C}$ values for poorly preserved bones (E Nitsch, personal communication). In some instances, the application of ultrafiltration improves significantly on previous dates, especially of Paleolithic samples, generally making them older (e.g. Bronk Ramsey et al. 2004; Higham et al. 2006; Jacobi et al. 2006). Although ultrafiltration certainly does not affect the dates of all bones-especially younger, Holocene, ones-it is impossible to predict which samples will be affected. Because of this and the observed improvement in C:N ratios and product texture, all bones routinely dated at ORAU are ultrafiltered with a 30kDa molecular weight cut-off (MWCO) filter.

Over recent years, interest in, and the application of, ultrafiltration to bone pretreatment procedures has increased (e.g. Beaumont et al. 2010). The technique, however, is not without problems. For example, it is recognized that ultrafiltration can result in reduced yields (e.g. Jørkov et al. 2007), making dating poorly preserved bones difficult. Also, higher molecular weight contaminants such as humic acids and conservation treatments, if not removed in the earlier stages of pretreatment, will effectively be concentrated in the final product. The necessity for thorough cleaning of the ultrafilters before use to remove humectants applied during the manufacturing process has been highlighted (e.g. Bronk Ramsey et al. 2004), and some remain concerned about the potential for ultrafilters to add contamination to samples (Hüls et al. 2009) or the effectiveness of the technique (e.g. Fülöp et al., these proceedings).

Individual collagen peptide $\alpha$ chains have molecular weights of $~ 90-120 \mathrm{kDa}$, with $\beta$ dimers weighing $\sim 200 \mathrm{kDa}$ and total collagen molecules $\sim 285-300 \mathrm{kDa}$ (e.g. Furthmayr and Timpl 1971; Zhang et al. 2006). Therefore, the application of 30kDa MWCO ultrafilters such as those used by Brown et al. (1988) and at ORAU (Bronk Ramsey et al. 2000; Brock et al. 2010) will retain the majority of collagen from the original specimen unless it is highly degraded to very short chain peptides (although Dobberstein et al. [2009] observed that $\alpha$-chains in archaeological collagen are either intact or absent, and are rarely degraded). Organic (e.g. fulvic) acids, broken-down short-chain degraded collagen and other proteins and peptides, soil-derived amino acids and salts have all been suggested as low molecular weight contaminants that could be removed by ultrafiltration (e.g. Brown et al. 1988; Higham et al. 2006). While these are all certainly feasible, there is little published evidence to support this, and it remains unclear why ultrafiltration can, in some instances, result in dramatically different dates.

Identifying what ultrafiltration does remove from bone samples is difficult for several reasons. What may be removed from one bone may be completely different to that removed from another, depending on the age and diagenetic state of the sample, and the depositional environment conditions. Suitable analytical techniques need to be identified to provide viable data that can be interpreted meaningfully. Many techniques may require more material than is available from valuable bone specimens, and without carrying out costly and unnecessary dating it is not always known which samples will produce different dates with and without ultrafiltration.

Here, we present the findings of a preliminary study into the suitability of a range of techniques with which to study the products of the routine "collagen" extraction procedure applied at ORAU with and without ultrafiltration. The study focused in particular on proteins (including analysis by SDSPAGE gel electrophoresis, LC-MS/MS, and amino acid analysis), salts, and trace metals, and the use of FTIR to characterize the products. The study necessitated an iterative approach, which involved varying starting weights and gelatinization and ultrafiltration conditions as the project progressed. We discuss our findings, and also propose future work to be undertaken. 


\section{F Brock et al.}

\section{METHODS AND SAMPLES}

\section{Samples}

The ideal bone specimens for this study would be those where ultrafiltration has been shown to make a difference to the ${ }^{14} \mathrm{C}$ date. However, despite the extensive bone archives kept at ORAU, sufficient material for this study was available for very few bones that fulfilled this criterion. It was also decided not to use archived collagen due to the difficulties in distinguishing between degradation caused over archaeological timescales and that which had occurred in the years in storage postextraction. Initial tests to determine the most suitable techniques to use for the study were carried out on 2 samples for which plenty of material was available, a bison vertebra from Alaska, estimated to be $\sim 60-70$ ka (sample LM), and a pig rib from the wreck of King Henry VIII's flagship the Mary Rose, which sank in AD 1545 (sample MR). Both samples are routinely used as laboratory standards at ORAU (Brock et al. 2007, 2010), and have each been dated several hundred times with ultrafiltration. Additional measurements undertaken on these samples processed without ultrafiltration indicate that, in these instances, ultrafiltration does not affect the dates. The bison vertebra is stained dark brown, commonly attributed to the presence of humics. Because these samples produced little or no solid $<30 \mathrm{kDa}$ products, comparisons were made between ultrafiltered and non-ultrafiltered products instead of $>$ and $<30 \mathrm{kDa}$ fractions.

Two samples for which ultrafiltration had resulted in a difference in dates were chosen for later tests, a Capra pyrenaica bone from Zafarraya, Spain (ZAF), and a cattle bone from Binchester, England (BIN). The sample from Zafarraya originally gave a date of 33,300 \pm 1200 BP (OxA-8999) when it was dated without ultrafiltration in 1999. Other samples dated at the same time by both the Oxford and Groningen laboratories gave similar dates, controversial due to their dating a late presence of Neanderthal fossils from the site. Because of this, the sample was redated in 2009 using ultrafiltration, giving a much older date of $>46,700$ BP (OxA-23198) (Wood et al. 2013). The bone itself was very clean, cream/white in color, unlikely to have been subjected to conservation treatments, and appeared very well preserved.

The cattle bone from the Roman site of Binchester originally gave a date of $1600 \pm 40$ BP (OxA8706) when it was dated without ultrafiltration in 1999. However, this date, along with 3 others that underwent similar pretreatment at ORAU at the same time, was anomalous with respect to the archaeological context and so was redated in 2003 using ultrafiltration (Marshall et al. 2010). The new date of $1714 \pm 26$ BP (OxA-12370) is more consistent with the context, and this sample provides a rare example of ultrafiltration affecting the age of a younger (Holocene) bone.

\section{Bone Pretreatment Methods}

Samples were drilled to powder or crushed to small chunks prior to pretreatment following routine collagen extraction and ultrafiltration procedures at ORAU (ORAU laboratory codes AG and AF respectively; Brock et al. 2010). Briefly, non-ultrafiltered treatment was as follows:

- MR bones were defatted using 1:1 chloroform:methanol at room temperature for $\sim 8 \mathrm{hr}$, before being left to air-dry thoroughly;

- Samples were demineralized with $\mathrm{HCl}(0.5 \mathrm{M})$ at room temperature, with 3 rinses over 20-24 hr;

- Humic acids were removed with $\mathrm{NaOH}(0.1 \mathrm{M})$, at room temperature for $30 \mathrm{~min}$;

- A further acid wash was carried out with $\mathrm{HCl}(0.5 \mathrm{M})$, at room temperature for $15 \mathrm{~min}$;

- All samples were thoroughly washed with ultrapure Milli-Q ${ }^{\mathrm{TM}}$ water after each of the above 3 stages;

- Samples were gelatinized in sealed $30-\mathrm{mL}$ tubes in $10 \mathrm{~mL}$ of pH 3 water at $75^{\circ} \mathrm{C}$ for $20 \mathrm{hr}$; 


\section{Bone “Collagen” Extraction Products for ${ }^{14} \mathrm{C}$ Dating}

- Gelatin solutions were then filtered with 45-90 $\mu \mathrm{m}$ Ezee-filters ${ }^{\mathrm{TM}}$ (Elkay, UK) to remove insoluble residue.

The samples that required ultrafiltration underwent the same initial pretreatment and were subsequently centrifuged in Vivaspin $15^{\mathrm{TM}} 30 \mathrm{kDa}$ MWCO ultrafilters (Sartorius, UK), which were thoroughly precleaned to remove any humectant, according to the protocol outlined by Brock et al. (2007). Unless otherwise stated, samples were spun until $~ 0.5-1.0 \mathrm{~mL}$ volume remained in the ultrafilter. The $>30 \mathrm{kDa}$ fraction was pipetted into a clean test tube, and $1 \mathrm{~mL}$ of ultrapure water added to the ultrafilter before being removed and added to the original fraction. The non-ultrafiltered and $>30 \mathrm{kDa}$ fractions were either stored frozen or freeze-dried for subsequent analysis, and the $<30 \mathrm{kDa}$ fraction stored frozen until required.

Initial pretreatments were undertaken using ORAU's routine starting weights ( 600 mg) depending on the original sample pretreatment yields (see Table 1). Further analysis of the LM and MR samples used $\sim 10 \%$ of the original starting weights, and the gelatinization and ultrafiltration conditions were varied as follows:

\section{Gelatinization Methods}

A: $75^{\circ} \mathrm{C}, 20 \mathrm{hr}, \mathrm{pH} 3$, as before;

B: $95^{\circ} \mathrm{C}, 50 \mathrm{~min}, 0.2 \mathrm{M} \mathrm{HCl}(\sim \mathrm{pH} 1)$ (after Semal and Orban 1995);

C: $58^{\circ} \mathrm{C}, 16 \mathrm{hr}, \mathrm{pH} 3$ (after Brown et al. 1988).

\section{Ultrafiltration Methods}

1. Spun to $\sim 0.5-1 \mathrm{~mL}$ and $>30 \mathrm{kDa}$ fraction collected as described above;

2. Spun to completion until no further reduction in volume of $>30 \mathrm{kDa}$ fraction was observed (usually to $\sim 0.3-0.4 \mathrm{~mL}$ );

3. Spun to $\sim 0.5-1 \mathrm{~mL}$ as above, then $10 \mathrm{~mL}$ of ultrapure water added and repeated before the $>30 \mathrm{kDa}$ fraction was collected as above.

4. As for method 3 above, but with a further $10 \mathrm{~mL}$ of ultrapure water added before spinning to completion (i.e. total water added $=20 \mathrm{~mL}$ ).

5. As for method 4 above, but with a further $10 \mathrm{~mL}$ ultrapure water added before spinning to completion (i.e. total water added $=30 \mathrm{~mL}$ ). Using this method, the $>30 \mathrm{kDa}$ fraction could not be reduced to below $1 \mathrm{~mL}$, even after extensive ( $>2 \mathrm{hr}$ ) centrifuging.

\section{SDS-PAGE}

SDS-PAGE (sodium dodecyl sulfate-polyacrylamide gel electrophoresis) was used to study the proteins present within the extracted products. Freeze-dried "collagen" samples ( 1-2 mg) were dissolved in $200 \mu \mathrm{L}$ of ultrapure Milli-Q water in microcentrifuge tubes and thoroughly mixed. The protein content of each sample was measured using the CBQCA protein quantitation kit (Invitrogen) according to manufacturer's instructions, to allow similar amounts of protein ( $50 \mu \mathrm{g})$ to be loaded onto the gels for each sample. Briefly, a standard curve was constructed using $0,0.1,0.5,1,5,10$, $20,40,60,80$, and $100 \mu \mathrm{g}$ of BSA. Samples of bone "collagen" were used undiluted and diluted $10 \times$. Reaction components were mixed according to manufacturer's instructions in a 96-well black microplate and allowed to react for $3 \mathrm{hr}$ of shaking at room temperature. Fluorescence values were measured with a PHERAstar Plus microplate reader (BMG Labtech). An average of undiluted and diluted measurements gave the final protein amounts.

For SDS-PAGE analysis, NuPAGE ${ }^{\circledR}$ LDS buffer (Invitrogen) was diluted 4-fold by addition to each sample. DTT was added as a reducing agent to a final concentration of $20 \mathrm{mM}$. The samples were 


\section{F Brock et al.}

then boiled at $95^{\circ} \mathrm{C}$ for $5 \mathrm{~min}$ in sealed microcentrifuge tubes. Precision Plus Protein ${ }^{\mathrm{TM}}$ dual color marker (Bio-Rad) was used as a molecular weight standard. Samples were loaded onto gradient gels (NuPAGE 4-12\% Bis-Tris, $1.5 \mathrm{~mm}$ ) that were then placed in tanks filled with NuPAGE MOPS SDS running buffer. Proteins were separated at $120-130 \mathrm{~V}$ for a minimum of $1.5 \mathrm{hr}$ and subsequently stained with Instant Blue Coomassie staining (Expedeon).

\section{LC-MS/MS}

Samples of proteins on the SDS-PAGE gels were digested with trypsin and analyzed using LC-MS/ MS LTQ Orbitrap (Thermo) to compare the proteins present above the $250 \mathrm{kDa}$ marker (i.e. those that had not entered the gels) in ultrafiltered products for all 4 of the bone samples. For comparison, samples were also taken of the $<20 \mathrm{kDa}$ proteins on the gels of the ultrafiltered products for all 4 bones and the $<30 \mathrm{kDa}$ fractions produced by ZAF and BIN.

Mascot v 2.4 (Matrixscience, London) software was used to analyze the LC-MS/MS data and identify proteins. The following Mascot parameters were used for database searching: Database: UniProt_SwissProt; Taxonomy: all; Enzyme: semi-trypsin; allow up to 2 missed cleavages. There was very little variation in protein identification if different search criteria were set, e.g. enzyme as trypsin, allow 3 missed cleavages. Proteins identified with Mascot scores $<60$ were not recorded.

\section{Amino Acid Analysis}

Amino acid analysis of the ultrafiltered and non-ultrafiltered products from all 4 bone samples was undertaken by the PNAC facility at the University of Cambridge. Each solid sample was dissolved in $10 \%$ acetic acid $(1 \mathrm{~mL})$, and an aliquot $(20 \mu \mathrm{L})$ added to $25 \mathrm{nM}$ norleucine internal standard and taken to dryness. After gas phase hydrolysis, the dried residue was dissolved in loading buffer and $\sim 20 \%$ injected onto a Biochrom 30 amino acid analyzer.

\section{Particle Size Distribution Analysis}

A Malvern Zetasizer was used to measure particle size distribution of the ultrafiltered and non-ultrafiltered products from LM and ZAF, as well as the $<30 \mathrm{kDa}$ fraction from ZAF. Each sample was dissolved in deionized water and measured 5 times.

\section{FTIR}

Infrared spectra of pretreated "collagen" were obtained using a Varian Excalibur series FTIR with a Specac Golden Gate ATR. Data were collected using Digilab Resolutions Pro 4.0 software. Each sample was run for 64 scans and each spectrum subject to background subtraction. One sample (the solvent washed, ultrafiltered fraction from ZAF) was measured on a Cary 640 FTIR spectrometer (Agilent) with a Pike GladiATR, and data were analyzed and collected as above.

\section{ICP-MS}

Solutions of the $>30$ and $<30 \mathrm{kDa}$ fractions after ultrafiltration from all 4 bones were submitted for analysis at the Natural History Museum, London, UK, using an Agilent 7700x ICP-MS.

\section{Ion Exchange Chromatography}

Solutions of the $>30$ and $<30 \mathrm{kDa}$ fractions after ultrafiltration from all 4 bones were submitted for analysis by ion exchange chromatography at the Department of Geography, University of Durham, UK, using Dionex ICS-1000 (cations) and DX-500 (anions) instruments. 


\section{RESULTS AND DISCUSSION}

\section{“Collagen" Extraction}

The percentage yield for each treatment of the 4 bone samples is given in Table 1. For all samples, the non-ultrafiltered treatment resulted in a similar or higher yield relative to the same ultrafiltered sample. Freeze-drying the $<30 \mathrm{kDa}$ fractions for BIN and ZAF resulted in solid products that resembled collagen in appearance; nothing comparable was retained for LM and MR.

Table 1 Starting weights, methods, and final yields for all samples pretreated during this study. Gelatinization and ultrafiltration methods (A-C and 1-5, respectively) are detailed in the main text. Where sample yields are given as "solution," samples were not freeze-dried but kept stored frozen for subsequent aqueous analysis by ICP-MS and ion exchange chromatography. (Note that samples LM9 and MR9 were discarded due to incorrect treatment procedures.)

\begin{tabular}{|c|c|c|c|c|c|c|}
\hline Sample & $\begin{array}{l}\text { Start wt } \\
(\mathrm{mg})\end{array}$ & $\begin{array}{l}\text { Ultra- } \\
\text { filtered }\end{array}$ & $\begin{array}{l}\text { Gelatinization } \\
\text { method }\end{array}$ & $\begin{array}{l}\text { Ultrafiltration } \\
\text { method }\end{array}$ & $\begin{array}{l}\text { “Collagen” } \\
\text { yield (\%) }\end{array}$ & $\begin{array}{l}<30 \mathrm{kDa} \\
\text { yield (\%) }\end{array}$ \\
\hline LM1 & 600 & No & A & $\mathrm{n} / \mathrm{a}$ & 12.0 & $\mathrm{n} / \mathrm{a}$ \\
\hline LM2 & 600 & Yes & A & 1 & 9.0 & - \\
\hline LM3 & 600 & Yes & A & 1 & Solution & - \\
\hline LM4 & 61.9 & Yes & A & 1 & 4.8 & - \\
\hline LM5 & 62.1 & Yes & A & 2 & 6.1 & - \\
\hline LM6 & 59.3 & Yes & A & 3 & 4.6 & - \\
\hline LM7 & 61.6 & Yes & A & 4 & 2.4 & - \\
\hline LM8 & 60.1 & Yes & A & 5 & 3.5 & - \\
\hline LM10 & 61.3 & Yes & B & 1 & 5.2 & - \\
\hline LM11 & 30.6 & Yes & B & 2 & 3.2 & - \\
\hline LM12 & 60.9 & Yes & B & 3 & 4.3 & - \\
\hline LM13 & 60.3 & Yes & B & 5 & 3.6 & - \\
\hline LM14 & 59.0 & Yes & $\mathrm{C}$ & 1 & 8.4 & - \\
\hline LM15 & 60.4 & Yes & $\mathrm{C}$ & 2 & 7.4 & - \\
\hline LM16 & 61.1 & Yes & $\mathrm{C}$ & 3 & 7.0 & - \\
\hline LM17 & 60.2 & Yes & $\mathrm{C}$ & 5 & 7.4 & - \\
\hline MR1 & 500 & No & A & $\mathrm{n} / \mathrm{a}$ & 20.5 & $\mathrm{n} / \mathrm{a}$ \\
\hline MR2 & 500 & Yes & A & 1 & 12.9 & - \\
\hline MR3 & 500 & Yes & A & 1 & Solution & - \\
\hline MR4 & 51.0 & Yes & A & 1 & 17.1 & - \\
\hline MR5 & 49.6 & Yes & A & 2 & 18.9 & - \\
\hline MR6 & 50.6 & Yes & A & 3 & 18.9 & - \\
\hline MR7 & 51.3 & Yes & A & 4 & 17.8 & - \\
\hline MR8 & 50.4 & Yes & A & 5 & 10.7 & - \\
\hline MR10 & 49.8 & Yes & B & 2 & 10.8 & - \\
\hline MR11 & 50.2 & Yes & B & 3 & 6.1 & - \\
\hline MR12 & 49.9 & Yes & $\mathrm{B}$ & 4 & 5.6 & - \\
\hline MR13 & 50.9 & Yes & B & 5 & 10.0 & - \\
\hline MR14 & 50.7 & Yes & $\mathrm{C}$ & 2 & 7.1 & - \\
\hline MR15 & 51.1 & Yes & $\mathrm{C}$ & 3 & 8.4 & - \\
\hline MR16 & 49.7 & Yes & $\mathrm{C}$ & 4 & 8.2 & - \\
\hline MR17 & 51.6 & Yes & $\mathrm{C}$ & 5 & 6.3 & - \\
\hline ZAF1 & 600 & No & $\mathrm{A}$ & $\mathrm{n} / \mathrm{a}$ & 3.0 & $\mathrm{n} / \mathrm{a}$ \\
\hline ZAF2 & 600 & Yes & A & 1 & 0.9 & 1.2 \\
\hline ZAF3 & 600 & Yes & A & 1 & Solution & Solution \\
\hline ZAF4 & 600 & Yes & A & 1 & 3.0 & 1.9 \\
\hline BIN1 & 990 & No & A & $\mathrm{n} / \mathrm{a}$ & 4.9 & $\mathrm{n} / \mathrm{a}$ \\
\hline BIN2 & 1010 & Yes & A & 1 & 4.8 & 0.5 \\
\hline BIN3 & 1010 & Yes & A & 1 & Solution & Solution \\
\hline
\end{tabular}




\section{F Brock et al.}

With all treatments, the ZAF sample resulted in an unusual cloudy white suspension after gelatinization that did not settle with time or centrifugation and that had not been recorded for the original measurement on this sample (see FTIR section below). Upon opening the sealed tubes of the LM and MR samples gelatinized at $95{ }^{\circ} \mathrm{C}$ and $\mathrm{pH} 1$, a strong odor was released. These samples often "melted" after initial freeze-drying (presumably due to the high acidity of the samples) and had to be redissolved in water and dried again one or more times before a stable solid product was formed.

The gelatinization conditions ( $58^{\circ} \mathrm{C}, \mathrm{pH} 3,16 \mathrm{hr}$ ) recommended by Brown et al. (1988) resulted in optimal yields for the poorly preserved, older LM samples, while the higher temperature used routinely at ORAU $\left(75^{\circ} \mathrm{C}, \mathrm{pH} 3,20 \mathrm{hr}\right.$ ) resulted in higher total yields of the younger, better-preserved MR samples, regardless of ultrafiltration method. The higher temperature and acidity gelatinization conditions of Semal and Orban (1995) tended to result in low yields, often the lowest of the 3 sets of conditions tested.

It is widely acknowledged that gelatinization conditions (most notably the strength and amount of acid used, the temperature, and the duration of the process) will affect the yield and final product of individual bones. The amount and concentration of acid utilized during hydrolysis of a poorly preserved bone is likely to differ from that required by a well-preserved sample. While these conditions (acid strength, temperature, duration, etc.) are usually well documented, the finer details of gelatinization processes employed by different laboratories, such as the reaction vessels and heating apparatus used, often go unreported. While it is clearly important to keep reaction vessels covered to prevent contamination of the samples, the nature of this cover will vary and may influence gelatinization conditions. For example, some laboratories gelatinize samples in vented tubes (e.g. KECK, UC Irvine; J Southon, personal communication), while at ORAU $10-\mathrm{mL}$ samples are gelatinized in sealed 30-mL tubes in an oven. Given the large headspace in the tubes used at ORAU, it is unlikely that there is sufficient pressure build-up to affect the gelatinization processes, but the sealed system may result in the actual gelatinization temperature being slightly higher than the expected $75^{\circ} \mathrm{C}$. Where samples are heated in dry blocks rather than ovens, it is likely that samples are gelatinized at temperatures lower than that at which the dry block is set, unless the temperature of the solution within a reaction vessel is measured and the set temperature adjusted accordingly.

When comparing the ultrafiltration procedures, the highest yields were generally for samples that had been spun to completion; the use of water rinses reduced the yields of the samples (although further increasing the amount of water used beyond $10 \mathrm{~mL}$ did not automatically result in a further decrease in yield). It should be noted that these pretreatments were only carried out once each, and should be repeated in duplicate or triplicate before more definitive conclusions about optimal gelatinization and ultrafiltration conditions can be reached.

\section{SDS-PAGE \& LC-MS/MS Analysis}

SDS-PAGE of non-ultrafiltered and ultrafiltered (>30kDa) samples from all 4 bones exhibited a stained "smear" across the whole molecular weight range of the gels (except for ZAF, which is generally below $75 \mathrm{kDa}$ ), including in the $<30 \mathrm{kDa}$ region, rather than distinct bands representing specific proteins (Figure 1). This staining is commonly assumed to represent a "degradation smear" of proteins of all sizes across a wide range (e.g. Semal and Orban 1995), which is possible given the range of potential proteins that could be extracted from bones and that $\mathrm{HCl}$ results in the partial dissolution of collagen-helices by peptide bond hydrolysis (Maspero et al. 2011). However, Dobberstein et al. (2009) hypothesized that this could also be indicative of cross-linking in archaeological bones, resulting in modified chain lengths and poor electrophoresis. 


\section{Bone "Collagen" Extraction Products for ${ }^{14} \mathrm{C}$ Dating}
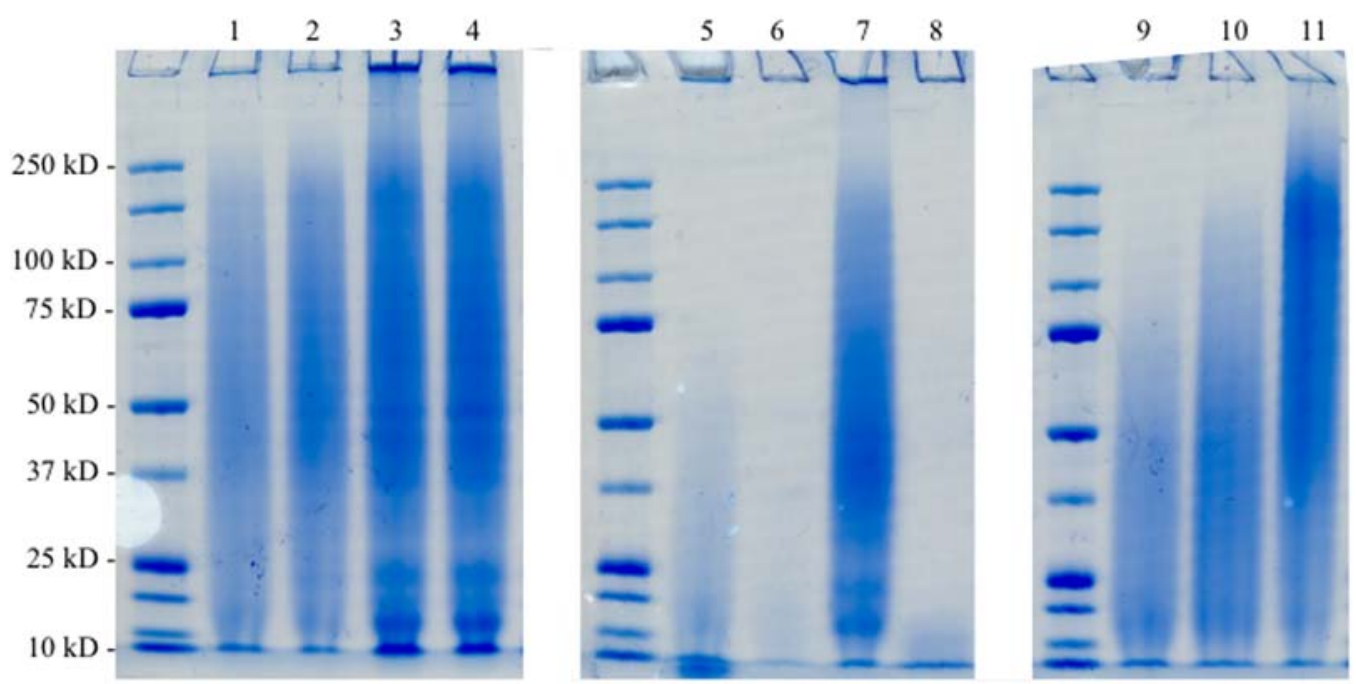

Figure 1 SDS-PAGE gels (from left to right) molecular weight markers; 1: LM1 (non-ultrafiltered); 2: LM2 (ultrafiltered, $>30 \mathrm{kDa}$ ); 3: MR1 (non-ultrafiltered); 4: MR2 (ultrafiltered, >30 kDa); 5: ZAF2 >30 kDa; 6: ZAF2 <30 kDa; 7: BIN2 $>30 \mathrm{kDa}$; 8: BIN2 <30 kDa; 9: LM5 (gelatinized at $75^{\circ} \mathrm{C}, \mathrm{pH} 3,20 \mathrm{hr}$ ), $>30 \mathrm{kDa}$; 10: LM10 (gelatinized at $95^{\circ} \mathrm{C}, \sim \mathrm{pH} 1$, $50 \mathrm{~min}$ ), >30 kDa; 11: LM14 (gelatinized at $58^{\circ} \mathrm{C}, \mathrm{pH} 3,16 \mathrm{hr}$ ), >30 kDa.

There was no visible difference between the SDS-PAGE gels for the ultrafiltered and non-ultrafiltered products from LM and MR (Figure 1, lanes 1-4), indicating that ultrafiltration is not removing all of the $<30 \mathrm{kDa}$ material present in these samples. Subsequently, both bones were ultrafiltered using $\sim 10 \%$ of the original starting weight of bone, to investigate whether the ultrafilters were being overloaded with protein, but again $<30 \mathrm{kDa}$ material was clearly present on the gels (not shown). Starting weight was not further reduced as the final products would have been too small for ${ }^{14} \mathrm{C}$ dating. The presence of $<30 \mathrm{kDa}$ material in the $>30 \mathrm{kDa}$ ultrafiltered products may be due to "fouling" of the filters, or to the electrostatic charge of membrane, and the $\mathrm{pH}$ of the gelatinization solution (e.g. Burns and Zydney 1999), and requires further investigation.

The ZAF ultrafiltered product (Figure 1, lane 5) indicated the presence of material $<30 \mathrm{kDa}$, especially at the very low molecular weight range, while the BIN ultrafiltered product (Figure 1, lane 7) did suggest reduced levels of $<\sim 15 \mathrm{kDa}$ material. The $<30 \mathrm{kDa}$ fractions for ZAF also showed traces of staining slightly above the $>30 \mathrm{kDa}$ range. It should be noted that the CBQCA analysis (which reacts with amine groups in proteins) gave strong readings for the $<30 \mathrm{kDa}$ fractions of ZAF and BIN, but little is seen on the gels, suggesting that these samples contain high proportions of low molecular weight amine groups, possibly from free hydrolyzed amino acids, which then run off the bottom of the gels.

A dark stain representing an aggregate of material that was too large to enter the gel ( $>250 \mathrm{kDa})$ was also observed for many of the samples analyzed, especially for the MR and BIN samples (Figure 1, lanes $3,4,7)$. It is unlikely that these aggregates formed during freeze-drying of the products, as boiling with LaemmLi buffer prior to loading the samples onto the gel would disrupt any such clusters.

SDS-PAGE analysis of the LM samples that had undergone different ultrafiltration conditions shows that increasing centrifugation times and water rinses still did not succeed in fully removing the $<30 \mathrm{kDa}$ fraction (data not shown). The gelatinization protocol recommended by Brown et al. (1988) $\left(58^{\circ} \mathrm{C}, \mathrm{pH} \mathrm{3}, 16 \mathrm{hr}\right.$ ) resulted in a higher proportion of high molecular weight proteins (i.e. 


\section{F Brock et al.}

less protein degradation) than those samples treated with the other gelatinization conditions (Figure 1, lane 11). When compared with the products of gelatinization at $58^{\circ} \mathrm{C}$ and $\mathrm{pH} 3 \mathrm{for} 16 \mathrm{hr}$, the poorly preserved LM samples did not support Semal and Orban's (1995) theory that gelatinizing at higher temperatures and $\mathrm{pH}$ for shorter periods of time can limit the degradation of long-chain proteins (Figure 1, lane 10), although this method does appear to result in higher molecular weight products than ORAU's current protocol in this instance (Figure 1, lane 9).

LC-MS/MS identified a range of proteins, including collagen $\alpha$-chains, in both the aggregate $(>250 \mathrm{kDa})$ and low $(<20 \mathrm{kDa})$ molecular weight range for the $>30 \mathrm{kDa}$ ultrafiltered samples from all 4 bones, although the specific proteins varied between samples (see Table 2 and Supplementary files online) and a much smaller range of proteins was detected in the lower molecular weight fractions. LC-MS/MS analysis of the material present in the $<30 \mathrm{kDa}$ fraction for ZAF and BIN included a much smaller range of proteins than recorded for the corresponding ultrafiltered $(>30 \mathrm{kDa})$ fractions (Table 2).

Table 2 Proteins identified by LCMSMS for all 4 bones studied, listed in order of identification confidence. Further details, and full protein identifications, are given in the Supplementary online information.

\begin{tabular}{|c|c|c|c|}
\hline \multirow[b]{3}{*}{ Sample } & \multicolumn{2}{|c|}{ Ultrafiltered, >30kDa } & \multirow{2}{*}{\begin{tabular}{|l|} 
Ultrafiltered, $<30 \mathrm{kDa}$ \\
$<20 \mathrm{kDa}$ \\
\end{tabular}} \\
\hline & $>250 \mathrm{kDa}$ & $<20 \mathrm{kDa}$ & \\
\hline & \multicolumn{3}{|l|}{ Protein description } \\
\hline LM & $\begin{array}{l}\text { Collagen } \alpha-1(\mathbf{I}) \text { chain } \\
\text { Chondroadherin } \\
\text { Collagen } \alpha-2(\mathbf{I}) \text { chain } \\
\text { Prothrombin } \\
\text { Pigment epithelium-derived factor } \\
\text { Vitronectin } \\
\text { Biglycan } \\
\text { Histone H2B } \\
\text { Collagen } \alpha-1(\text { II) chain } \\
\text { Collagen } \alpha-2(\mathbf{I}) \text { chain } \\
\text { Actin } \\
\text { Lumican } \\
\text { Histone H4 } \\
\text { Coronin-like protein crn } 1\end{array}$ & $\begin{array}{l}\text { Collagen } \alpha-1(I) \text { chain } \\
\text { Collagen } \alpha-2(I) \text { chain } \\
\text { Chondroadherin } \\
\text { Pigment epithelium-derived factor } \\
\text { Ubiquitin-60S ribosomal protein } \\
\text { L40 }\end{array}$ & N.A. \\
\hline MR & $\begin{array}{l}\alpha \text {-2-HS-glycoprotein } \\
\text { Collagen } \alpha \text {-1(I) chain } \\
\text { Pigment epithelium-derived factor } \\
\text { Collagen } \alpha \text {-2(I) chain } \\
\text { Secreted phosphoprotein } 24 \\
\text { Prothrombin } \\
\text { Vitronectin } \\
\text { Periostin } \\
\text { Vitamin K-dependent protein C } \\
\text { Chondroadherin } \\
\text { Ubiquitin-60S ribosomal protein } \\
\text { L40 } \\
\text { Matrix Gla protein } \\
\text { SPARC (osteonectin) } \\
\text { Vitamin K-dependent protein S } \\
\text { C-reactive protein } \\
\text { Dermatopontin }\end{array}$ & $\begin{array}{l}\text { Collagen } \alpha-2(I) \text { chain } \\
\text { Collagen } \alpha-1(I) \text { chain } \\
\alpha-2-H S-g l y c o p r o t e i n \\
\text { Secreted phosphoprotein } 24 \\
\text { C-reactive protein } \\
\text { Dermatopontin }\end{array}$ & N.A. \\
\hline
\end{tabular}




\section{Bone “Collagen” Extraction Products for ${ }^{14} \mathrm{C}$ Dating}

Table 2 Proteins identified by LCMSMS for all 4 bones studied, listed in order of identification confidence. Further details, and full protein identifications, are given in the Supplementary online information. (Continued)

\begin{tabular}{|c|c|c|c|}
\hline \multirow[b]{3}{*}{ Sample } & \multicolumn{2}{|c|}{ Ultrafiltered, >30kDa } & \multirow{2}{*}{\begin{tabular}{|l|} 
Ultrafiltered, $<30 \mathrm{kDa}$ \\
$<20 \mathrm{kDa}$
\end{tabular}} \\
\hline & $>250 \mathrm{kDa}$ & $<20 \mathrm{kDa}$ & \\
\hline & \multicolumn{3}{|l|}{ Protein description } \\
\hline ZAF & $\begin{array}{l}\text { Collagen } \alpha-2(I) \text { chain } \\
\text { Collagen } \alpha-1(I) \text { chain } \\
\text { Actin } \\
\text { Actin-1 } \\
\text { Hemoglobin subunit } \beta \\
\text { Short-chain collagen C4 }\end{array}$ & $\begin{array}{l}\text { Collagen } \alpha-1(I) \text { chain } \\
\text { Collagen } \alpha-2(I) \text { chain } \\
\text { Short-chain collagen C4 }\end{array}$ & $\begin{array}{l}\text { Collagen } \alpha-1(I) \text { chain } \\
\text { Collagen } \alpha-2(I) \text { chain } \\
\text { Short-chain collagen C4 }\end{array}$ \\
\hline BIN & $\begin{array}{l}\text { Junction plakoglobin } \\
\text { Pigment epithelium-derived factor } \\
\alpha \text {-2-HS-glycoprotein } \\
\text { Collagen } \alpha \text {-1(I) chain } \\
\text { Prothrombin } \\
\text { Desmoplakin } \\
\text { Desmoglein-1 } \\
\text { Chondroadherin } \\
\text { Collagen } \alpha \text {-2(I) chain } \\
\text { Hornerin } \\
\text { Vitronectin } \\
\text { Secreted phosphoprotein } 24 \\
\text { Biglycan } \\
\text { Annexin A1 } \\
\text { Thioredoxin-1 } \\
\text { Actin, cytoplasmic } 1 \\
\text { Plakophilin-1 } \\
\text { Collagen } \alpha \text {-2(XI) chain } \\
\text { Matrix Gla protein } \\
\text { Complement component C9 } \\
\text { Filaggrin-2 } \\
\text { Calgranulin-B } \\
\text { Lysozyme C } \\
\text { L-lactate dehydrogenase A chain } \\
\text { Vitamin K-dependent protein S } \\
\text { Coagulation factor IX } \\
\text { Calgranulin-A } \\
\alpha \text {-enolase } \\
\beta \text {-casein } \\
\text { Ubiquitin-60S ribosomal protein } \\
\text { L40 }\end{array}$ & $\begin{array}{l}\text { Collagen } \alpha-1(I) \text { chain } \\
\text { Collagen } \alpha-2(I) \text { chain } \\
\text { Thioredoxin-1 } \\
\text { Hornerin } \\
\text { Desmoplakin } \\
\text { Lysozyme C-2 } \\
\text { Prolactin-inducible protein ho- } \\
\text { molog } \\
\alpha \text {-2-HS-glycoprotein } \\
\text { Calgranulin-B } \\
\text { Junction plakoglobin }\end{array}$ & $\begin{array}{l}\text { Collagen } \alpha-1(\mathbf{I}) \text { chain } \\
\text { Thioredoxin-1 } \\
\text { Lysozyme C } \\
\text { Putative trypsin-6 } \\
\text { Actin, cytoplasmic } \\
\text { Collagen } \alpha-2(\mathbf{I}) \text { chain } \\
\text { Calgranulin-B } \\
\beta \text {-casein } \\
\text { Calgranulin-A } \\
\text { Hemoglobin subunit delta } \\
\text { Uncharacterized protein } \\
\text { C315R }\end{array}$ \\
\hline
\end{tabular}

Collagen $\alpha-1$ and $\alpha-2$ chains were detected by LC-MS/MS in both the high and low molecular weight ranges of the ultrafiltered products for all of the bones, as well as the $<30 \mathrm{kDa}$ products for BIN and ZAF, contrary to Dobberstein et al.'s (2009) hypothesis that collagen $\alpha$-chains are either present intact or absent in archaeological bones, and rarely present as degraded proteins. A range of other proteins were detected in all 4 bones (Table 2), including some known to be non-collagenous bone proteins (e.g. matrix Gla protein (osteocalcin) and $\alpha$-2-HS-glycoprotein), some previously reported in archaeological bones (e.g. haemoglobin and albumin; Collins et al. 2002), some known for their potential to bind to type I collagen proteins (e.g. biglycan, osteonectin, vitronectin; e.g. Pri- 


\section{F Brock et al.}

godich and Vesely 1997; Di Lullo et al. 2002, and references therein), and some proteins such as actin and ubiquitin that are found in almost all eukaryotic cells). No bacterial proteins were identified in any samples. No specific proteins were identified as being completely removed by ultrafiltration from any of the 4 bone samples studied.

It is unsurprising that non-collagenous proteins are present in the "collagen" extracts, as the processes involved in the extraction procedure are not capable of discriminating between proteins. Some of the proteins detected may have come from contact with human skin during the analytical procedures (e.g. dermcidin, detected in BIN but not listed in Table 2 as known to be a contaminant). Keratin and serum albumin were detected in all samples, but are also not listed in Table 2; while both may originate from bone samples themselves, keratin is a frequent contaminant in mass spectrometry-based proteomics, being commonly introduced during the processing of the sample, and bovine serum albumin is used as a quality control standard in mass spectrometry.

The form and structure of the "aggregate" observed at the top of the SDS-PAGE gels is not known, whether it is a mass of cross-linked substances with proteins and other organic and inorganic substances bound to one another, or whether during or post-gelatinization the larger protein chains form irregular coils and structures effectively "trapping” other, smaller compounds, e.g. actin ( 42 kDa) and pigment epithelium-derived factor ( $\sim 50 \mathrm{kDa})$, which would normally have been expected to have entered the SDS-PAGE gel.

It is important to note the limitations of both SDS-PAGE and LC-MS/MS for this type of study. LCMS/MS, when coupled to trypsin digestion as in this study, can sequence protein fragments as long as they typically have a molecular weight of $>600 \mathrm{D}$. The sample heterogeneity introduced by protein degradation will, however, reduce the sensitivity of the combined SDS-PAGE, trypsin digestion and LC-MS/MS approach. Any amino acids or small-chain proteins (about $<10 \mathrm{kDa}$ ) are likely to have run off the gel and not been stained, and it is also impossible to determine how much of the sample is present in the aggregate that does not enter the gel. SDS-PAGE gels can be difficult to successfully reproduce for publication, and to interpret visually. Some gels were not shown above due to a lack of clarity in the scanned images. ImageJ software (http://rsb.info.nih.gov/ij/) was used to plot the density of the staining along lanes to aid interpretation of some gels.

\section{Amino Acid Analysis}

Results of the amino acid analysis are given in Table 3. There is little difference in relative amino acid concentrations between corresponding ultrafiltered and non-ultrafiltered products from any of the bones. Combining the total amino acid values for each sample gives an approximation of total protein content (Table 3). This excludes cystine/cysteine and tryptophan, although these are not present in collagen (Gillespie 1989), and are usually present in very small quantities in other proteins. This value suggests that each sample is only $\sim 75-80 \%$ proteinaceous, and this proportion generally decreases with ultrafiltration. However, it should be noted that 20-50\% wt collagen in archaeological samples is not hydrolyzable and therefore not detected by amino acid analysis (van Klinken 1999).

\section{Particle Size Distribution}

Ultrafiltered and non-ultrafiltered samples of LM and ZAF, as well as the $<30 \mathrm{kDa}$ fraction of ZAF, were each analyzed 5 times, and average values of particle size distribution vs. scattered intensity are shown in Figure 2. Interpretation of the data is not straightforward, but the ultrafiltered fraction for LM appears to contain slightly smaller particles than the corresponding non-ultrafiltered fraction, although the reason for this is unclear, and may just reflect sample heterogeneity. 
Table 3 Amino acid content of non-ultrafiltered (LM1, MR1, ZAF1, BIN1) and ultrafiltered (LM2, MR2, ZAF4, BIN2) fractions from all 4 bones. Sample numbers refer to samples listed in Table 1. Total protein is calculated approximately as the sum of all amino acids listed in the table.

\begin{tabular}{|c|c|c|c|c|c|c|c|c|c|c|c|c|c|c|c|c|c|c|}
\hline 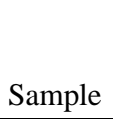 & $\begin{array}{l}\text { Asp } \\
\%\end{array}$ & $\begin{array}{l}\text { Th } \\
\%\end{array}$ & $\begin{array}{l}\text { Ser } \\
\%\end{array}$ & $\begin{array}{l}\text { Glu } \\
\%\end{array}$ & $\%$ & $\begin{array}{l}\text { Ala } \\
\%\end{array}$ & $\begin{array}{l}\text { Val } \\
\%\end{array}$ & $\begin{array}{l}\text { Met } \\
\%\end{array}$ & $\begin{array}{l}\text { Ile } \\
\%\end{array}$ & $\begin{array}{l}\text { Leu } \\
\%\end{array}$ & $\begin{array}{l}\text { Tyr } \\
\%\end{array}$ & $\begin{array}{l}\text { he } \\
\%\end{array}$ & $\begin{array}{l}\text { His } \\
\%\end{array}$ & $\begin{array}{l}\text { Lys } \\
\%\end{array}$ & $\begin{array}{l}\text { Arg } \\
\%\end{array}$ & $\begin{array}{l}\mathrm{HO}- \\
\text { Pro } \\
\%\end{array}$ & $\begin{array}{l}\text { Pro } \\
\%\end{array}$ & $\begin{array}{l}\text { Total } \\
\text { protein } \\
\mathrm{mg} / \mathrm{g}\end{array}$ \\
\hline 1 & 60 & 10 & 30 & 10 & 217 & 9.2 & 24 & 0.7 & 1.4 & 31 & 0.4 & 20 & 08 & 3.9 & 8.6 & 11.5 & 12.6 & 822.9 \\
\hline & 5.4 & 1.9 & 3.1 & 10.9 & 21. & 9. & & 0 & & & & & 0.8 & 3.8 & 8 & 11.7 & & \\
\hline MR1 & 6.1 & 1 & 3.0 & 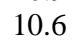 & 20. & 8.9 & 2 & 0 & 1.2 & 3 & & 2 & 1.1 & 3.8 & 0 & 11.4 & 12.9 & 8 \\
\hline & & & & & & & & & & & & & & & & 4 & & \\
\hline & & & & & & & & & & & & & & & & 8 & & \\
\hline & 4.9 & 2.2 & 2.7 & 2 & 22 & 9.7 & 2. & 0 & 1 . & 2.8 & d & 1. & 0 & 4.0 & 3 & 11.9 & 3.2 & 7 \\
\hline & 0.0 & 1. & 3.0 & & 21.3 & 9.0 & 2.5 & 0.7 & 1.4 & 3.2 & 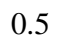 & 2.0 & 0.9 & 3.9 & 8.8 & 11.6 & 13.0 & 810.2 \\
\hline BIN2 & 5.4 & 1.9 & 3.0 & 10.8 & 21.4 & 9.1 & 2.6 & 0.8 & 1.4 & 3.2 & 0.5 & 2.0 & 0.8 & 3.8 & 8.9 & 11.3 & 13.0 & 821.9 \\
\hline
\end{tabular}
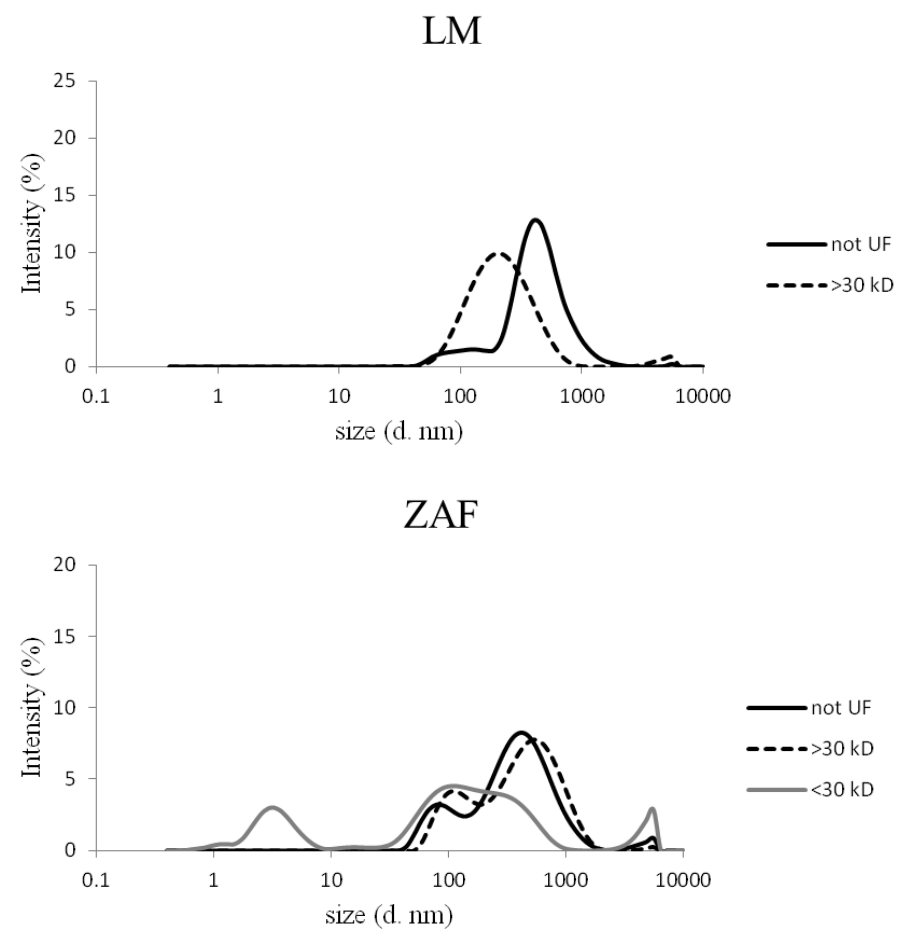

Figure 2 Particle size distribution plots vs. intensity from a) LM and b) ZAF products. Plotted values are averages of 5 measurements taken for each sample.

There is little difference between the ultrafiltered and non-ultrafiltered fractions of ZAF (Figure 2), with both containing particles within 2 distinct size ranges, $100 \mathrm{~nm}$ and just under $1000 \mathrm{~nm}$, and with no material $<10 \mathrm{~nm}$ present. In contrast to the LM samples, there may be a slight shift towards higher particle sizes in the $>30 \mathrm{kDa}$ ultrafiltered fraction compared with the non-ultrafiltered material. However, the $<30 \mathrm{kDa}$ fraction shows a very different distribution. A sample of mixed sizes will have different intensities; many small particles will scatter the same intensity as just a few large ones. In this case, approximately one third of the light intensity is scattered by particles $<10 \mathrm{~nm}$ in size, and approximately two thirds scattered by particles between $\sim 30$ and $1000 \mathrm{~nm}$. This is likely to be caused by $>99 \%$ particle numbers being below $10 \mathrm{~nm}$, and maybe $<1 \%$ particle numbers $>10 \mathrm{~nm}$. 


\section{F Brock et al.}

Therefore, the particle size distribution analysis suggests that ultrafiltration is more effective at removing the $<30 \mathrm{kDa}$ fraction than the SDS-PAGE analysis may indicate.

\section{FTIR}

Little or no difference was observed between the FTIR spectra of the corresponding ultrafiltered and non-ultrafiltered products from LM, MR and BIN. However, an additional peak in the C-H stretching region at $\sim 2930 \mathrm{~cm}^{-1}$ appears in the spectra for both the $>30 \mathrm{kDa}$ ultrafiltered and non-ultrafiltered products from ZAF, which is absent in the corresponding $<30 \mathrm{kDa}$ fraction (Figure 3 ).

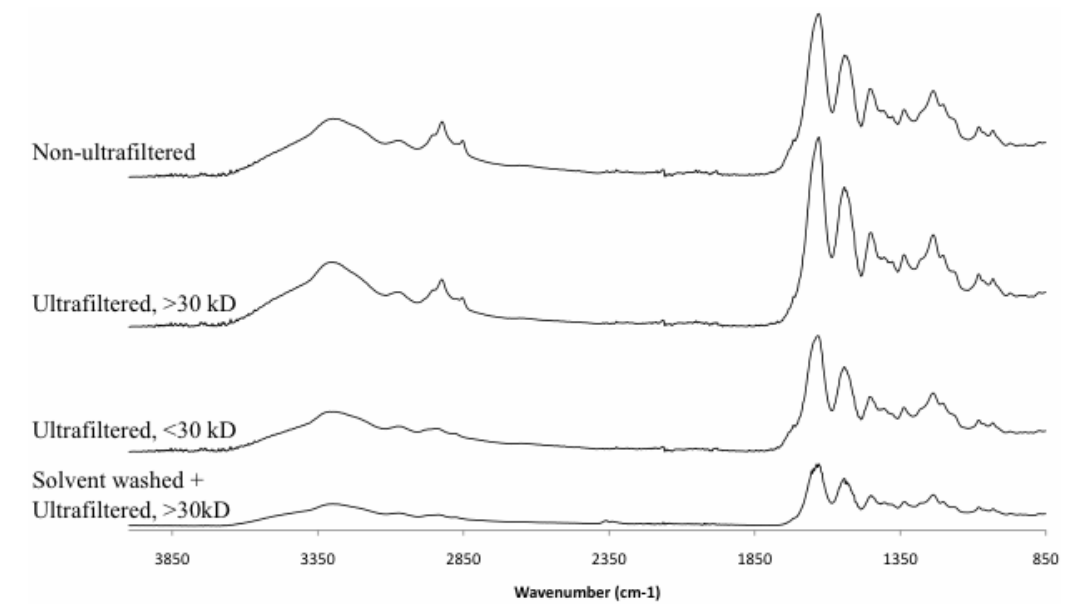

Figure 3 FTIR spectra of fractions from ZAF. An additional peak is present in the C-H stretching region at $\sim 2930 \mathrm{~cm}^{-1}$ in the non-ultrafiltered and $>30 \mathrm{kDa}$ fractions.

Yuan et al. (2007) reported a similar peak in FTIR spectra of oracle bones that dated too old. Subsequent solvent washing of these bones resulted in the disappearance of this peak in the FTIR spectra and expected ${ }^{14} \mathrm{C}$ dates. Sequential washes of ZAF bone powder with acetone, methanol, and chloroform prior to pretreatment resulted in an ultrafiltered date of $>46,700 \mathrm{BP}$ (and disappearance of the peak $\sim 2930 \mathrm{~cm}^{-1}$ in the FTIR spectrum; Figure 3), corroborating the previous ultrafiltered date (Table 4). The sample is currently being redated without ultrafiltration to confirm the original $33,300 \pm 1200 \mathrm{BP}$ date. Although the $\mathrm{CH}_{2}$ peak is not diagnostic, records suggest it is unlikely that this sample had been subject to conservation treatments. The cave of Zafarraya is in an area of numerous small hydrocarbon basins in the Betic Cordillera of southern Spain (Fernández et al. 1996), and it is possible that hydrocarbons may have penetrated upwards through the rock (either within groundwater or as gases) and into the sample. The presence of a hydrocarbon component within the sample may explain the unusual white suspension observed after gelatinization, but it is interesting to note that the C:N ratio and $\delta^{13} \mathrm{C}$ values of the "collagen" did not vary between treatments (Table 4). It should be highlighted that ultrafiltration usually results in lower yields than nonultrafiltered products from the same specimen. The low (1\%) yield of the non-ultrafiltered product for ZAF reported in Table 4 is therefore somewhat surprising in comparison with the ultrafiltered yield of 5.4\%. The reason for this discrepancy is unclear, and no records to explain it exists from the original treatment (undertaken in 1999). 


\section{Bone “Collagen” Extraction Products for ${ }^{14} \mathrm{C}$ Dating}

Table 4 Radiocarbon date, \% yield, $\delta^{13} \mathrm{C}$, and C: $\mathrm{N}$ ratio for the products of 3 different pretreatment protocols applied to ZAF.

\begin{tabular}{l|lllcl}
\hline Pretreatment & \% yield & $\delta^{13} \mathrm{C}(\%$ ) & $\mathrm{C}: \mathrm{N}$ ratio & ${ }^{14} \mathrm{C}$ age $(\mathrm{BP})$ & OxA- \\
\hline Not ultrafiltered & 1.0 & -19.1 & 3.3 & $33,300 \pm 1200$ & 8999 \\
Ultrafiltered & 5.4 & -18.9 & 3.3 & $>46,700$ & 23198 \\
Solvent wash + ultrafiltered & 1.9 & -19.1 & 3.2 & $>46,700$ & 26440 \\
\hline
\end{tabular}

\section{Ion Exchange Chromatography}

Ion exchange chromatography was undertaken to measure concentrations of a suite of anions and cations in the $>30$ and $<30 \mathrm{kDa}$ solutions following ultrafiltration of all 4 bone samples. The results are given in Table 5 (nitrate, nitrite, ammonium, and magnesium were not detected in any of the solutions). Higham et al. (2006) have proposed that ultrafiltration removes salts from samples (although no data has been published to support this), and attribute the improved texture and "handle-ability" of ultrafiltered products to salt removal. However, the data from this study indicate that concentrations of anions and cations, in particular chloride (and sodium in BIN), are considerably higher in the $>30 \mathrm{kDa}$ fraction than in the $<30 \mathrm{kDa}$ solution, indicating that ultrafilters may not be removing salts as thoroughly as previously thought.

Table 5 Ion exchange chromatography data for the $>30$ and $<30 \mathrm{kDa}$ solutions for each of the 4 bones studied.

\begin{tabular}{lllllllll}
\hline \multirow{2}{*}{ Sample } & Fraction & $\begin{array}{l}\text { Fluoride } \\
\mathrm{mg} / \mathrm{L}\end{array}$ & $\begin{array}{l}\text { Chloride } \\
\mathrm{mg} / \mathrm{L}\end{array}$ & $\begin{array}{l}\text { Sulfate } \\
\text { (as S) } \\
\mathrm{mg} / \mathrm{L}\end{array}$ & $\begin{array}{l}\text { Phosphate } \\
\text { (as P) } \\
\mathrm{mg} / \mathrm{L}\end{array}$ & $\begin{array}{l}\text { Sodium } \\
\mathrm{mg} / \mathrm{L}\end{array}$ & $\begin{array}{l}\text { Potassium } \\
\mathrm{mg} / \mathrm{L}\end{array}$ & $\begin{array}{l}\text { Calcium } \\
\mathrm{mg} / \mathrm{L}\end{array}$ \\
\hline $\mathrm{LM}$ & $>30 \mathrm{kDa}$ & 2.2 & 294.4 & 3.6 & 19.4 & 38.2 & 14.2 & 61.4 \\
& $<30 \mathrm{kDa}$ & 1.5 & 124.9 & 1.8 & 9.5 & 18.9 & 6.9 & 31.8 \\
$\mathrm{MR}$ & $>30 \mathrm{kDa}$ & 0.8 & 386.4 & 3.4 & n.d. & 46.8 & 19.8 & 60.8 \\
& $<30 \mathrm{kDa}$ & 0 & 49.0 & 1.4 & n.d. & 19.1 & 7.3 & n.d. \\
ZAF & $>30 \mathrm{kDa}$ & 1.8 & 86.4 & 3.0 & 5.0 & 36.8 & 12.8 & 62.4 \\
& $<30 \mathrm{kDa}$ & 0 & 34.8 & 1.4 & n.d. & 17.9 & 6.4 & n.d. \\
BIN & $>30 \mathrm{kDa}$ & 14.0 & 739.6 & 6.0 & n.d. & 640.8 & 27.6 & 69.8 \\
& $<30 \mathrm{kDa}$ & 0.5 & 48.2 & 1.6 & n.d. & 32.8 & 9.9 & 30.6 \\
\hline
\end{tabular}

\section{ICP-MS}

Trace metal concentrations of the associated $>30$ and $<30 \mathrm{kDa}$ fractions for each bone were measured using ICP-MS. The results are given in Table 6 (with the exception of data for Ag, very low levels of which were detected in only 2 of the 8 samples).

Table 6 ICP-MS data for the $>30$ and $<30 \mathrm{kDa}$ solutions for each of the 4 bones studied.

\begin{tabular}{llrllrlll}
\hline & & $\mathrm{Cr}$ & $\mathrm{Mn}$ & $\mathrm{Fe}$ & $\mathrm{Ni}$ & $\mathrm{Cu}$ & $\mathrm{Zn}$ & $\mathrm{Pb}$ \\
Sample & Fraction & \multicolumn{1}{c}{$\mathrm{ppb}$} & $\mathrm{ppb}$ & $\mathrm{ppb}$ & $\mathrm{ppb}$ & $\mathrm{lpb}$ & $\mathrm{ppb}$ & \multicolumn{1}{c}{$\mathrm{ppb}$} \\
\hline LM & $>30 \mathrm{kDa}$ & 182.4 & 341.7 & 49,650 & 11.0 & 1363.1 & 328.3 & 16.7 \\
& $<30 \mathrm{kDa}$ & 12.7 & 304.6 & 32,709 & 4.6 & 735.4 & 131.9 & 0 \\
$\mathrm{MR}$ & $>30 \mathrm{kDa}$ & 171.2 & 0 & 980.1 & 12.8 & 44.7 & 570.5 & 10.2 \\
& $<30 \mathrm{kDa}$ & 12.4 & 0 & 0 & 0 & 82.4 & 155.6 & 2.9 \\
$\mathrm{ZAF}$ & $>30 \mathrm{kDa}$ & 328.5 & 0 & 0 & 0 & 333.0 & 2410.1 & 43.1 \\
& $<30 \mathrm{kDa}$ & 13.5 & 0 & 0 & 0 & 8.7 & 160.1 & 1.9 \\
$\mathrm{BIN}$ & $>30 \mathrm{kDa}$ & 290.6 & 234.0 & 4611.7 & 10.9 & 95.4 & 814.0 & 6.0 \\
& $<30 \mathrm{kDa}$ & 14.7 & 234.1 & 463.2 & 3.5 & 1579.9 & 129.9 & 1.4 \\
\hline
\end{tabular}




\section{F Brock et al.}

Different elements were detected at different levels in each of the 4 bones specimens, as was expected for bones from such different depositional environments. Concentrations of $\mathrm{Cr}, \mathrm{Mn}, \mathrm{Ni}$, and $\mathrm{Pb}$ were low for all samples, but Fe (except ZAF) and Zn (except LM), and to a lesser extent, $\mathrm{Cu}$, were considerably higher. Fe and $\mathrm{Zn}$ concentrations tended to be significantly higher in the $>30 \mathrm{kDa}$ fractions than the $<30 \mathrm{kDa}$ ones; the reverse was true for $\mathrm{Cu}$. It should be noted that the iron levels in the LM sample were much higher than expected, and data are given as approximate quantitative values, concentrations being much higher than the accompanying standards. Although the data is difficult to interpret, the high concentrations of certain metals, especially iron and, to a lesser extent, zinc and copper, in the $>30 \mathrm{kDa}$ fractions suggest that these metals may be complexed with, or chelated to, organics within the samples. These organics may or may not be proteinaceous; humic acids, for example, have a high complexation capacity and are known to be able to strongly influence trace metal concentrations in the environment (Burba et al. 1995). The exceptionally high iron levels in the LM sample suggest that the dark brown/orange color of the bone may indeed be due to mineral staining as well as, or instead of, the presence of humics as is commonly assumed.

\section{Fulvic Acids}

Brown et al. (1988) proposed that ultrafiltration may remove some smaller molecular weight organic (e.g. fulvic) acids, although it seems likely that such substances would have been removed from the sample earlier in the pretreatment process. Attempts to investigate the removal of fulvic acids by ultrafiltration in this study were hampered by the lack of a suitable technique. UV-Vis spectrometry is commonly used to analyze the presence of fulvic and humic acids in environmental and soil science studies. However, fulvic and humic acids are known to produce featureless curves (Havers et al. 1998), and their molar absorptivity is similar to that of proteins, making their identification in the samples from this study, especially without prior resin extraction, almost impossible. Furthermore, some reports suggest that the UV-Vis spectra of humic and fulvic acids can be dependent on a range of conditions including $\mathrm{pH}$, ionic strength, and extent of complexation with higher valent metal ions (e.g. MacCarthy and Rice 1985) —although other authors dispute this, at least in part (e.g. Ghabbour and Davies 2009)—which further hinders comparison of spectra from the different bone specimens in this study.

\section{FURTHER WORK}

The work presented here highlights the potential for considerable further study into the gelatinization and ultrafiltration processes employed in bone pretreatment for ${ }^{14} \mathrm{C}$ dating, both at ORAU and elsewhere. Further work will be undertaken at ORAU (some of which has already begun). This includes the following:

- Optimization of gelatinization conditions (with specific regard to the temperature used) to ensure that samples, in particular poorly preserved ones, are not unnecessarily degraded during the process and potentially dateable specimens are not lost.

- Improving the efficiency of ultrafilters, in particular by considering the $\mathrm{pH}$ (and possibly also the temperature) of the solution filtered. It has previously been reported that the $\mathrm{pH}$ can have a significant impact on the transport of proteins through ultrafilter membranes by affecting the electrostatic charge of the membrane itself (e.g. Burns and Zydney 1999), and it is quite possible that the effectiveness of the process could be improved by reducing the acidity of the gelatin solution prior to ultrafiltration.

- Further understanding the nature of the protein "aggregate" observed for many of the samples, and how this can more effectively be broken down (or its formation avoided at all, if it is a product of the gelatinization process itself). 


\section{Bone "Collagen” Extraction Products for ${ }^{14}$ C Dating}

Further studies will continue to utilize SDS-PAGE, LC-MS/MS, and amino acid analysis. The potential of size exclusion chromatography and MALDI-MS (as recently applied by Wilson et al. 2012) to this study will also be investigated. If further inorganic analysis (ICP-MS and/or ion exchange chromatography) is undertaken, then measurements will be compared for ultrafiltered and non-ultrafiltered fractions of the same bone samples, and standard solutions of known concentration will be ultrafiltered to investigate the equilibrium between the $<30$ and $>30 \mathrm{kDa}$ solutions.

Work on modern bone as a comparison to the samples described here is already underway. However, as Beaumont et al. (2010) highlighted, a significant obstacle in studies such as these that aim to investigate exactly what is removed by ultrafilters when they result in significant shifts in ${ }^{14} \mathrm{C}$ dates is the lack of well-characterized contaminated bone of known age. Further dates will be undertaken to try and identify more bones where ultrafiltration does affect the ${ }^{14} \mathrm{C}$ age and subsequent analysis will focus in particular on amino acid analysis of the $<30 \mathrm{kDa}$ fraction removed. Reaching definitive conclusions regarding what ultrafilters remove from bone "collagen" is rendered more challenging because of the wide spectrum of diagenetic processes and contamination influences on archaeological bone.

\section{CONCLUSIONS}

The work presented herein is only a preliminary investigation into the final products of "collagen" extraction from bone specimens for ${ }^{14} \mathrm{C}$ dating, and it is difficult to draw valid conclusions from analysis of samples from such a small and varied data set. However, the data clearly shows that the final product of the collagen extraction process applied at ORAU (with or without ultrafiltration) appears to be an aggregate of proteins of different molecular weights, including collagen, along with associated inorganic complexes and potentially non-proteinaceous organic substances. A greater understanding of the structure and content of this aggregate material and how it can either be broken down (or if its formation can be avoided if it is a byproduct of the pretreatment process itself) is needed to be able to improve the effectiveness of the ultrafiltration protocol applied at ORAU.

While ultrafiltration is clearly removing some $<30 \mathrm{kDa}$ material from bones (most likely as hydrolyzed amino acids as well as other unidentified organic fragments), not all of this molecular weight fraction is removed with current procedures. This cannot be remedied simply by reducing the amount of protein loaded into the ultrafilter and/or increasing centrifugation times and water rinses. However, it is clearly better to be removing some of the $<30 \mathrm{kDa}$ fraction-containing potentially contaminating substances of a different age to the specimen to be dated - than none of it. Previous studies demonstrate that the technique does result in improved contaminant removal, as evidenced by the improved C:N ratios of the product, and can significantly improve ${ }^{14} \mathrm{C}$ dates (as reported by Bronk Ramsey et al. 2004 and Higham et al. 2006). Although it is still unclear precisely what substances ultrafiltration does remove, it is not yet possible to identify those samples that will benefit from ultrafiltration without dating them. However, because of the improved C:N ratios and quality of the products, the technique will continue to be applied to all bones routinely treated at ORAU (following careful cleaning of the filters and with appropriate QA procedures in place) until evidence arises to suggest otherwise.

As expected, different gelatinization conditions result in different yields and molecular weight products for the same samples. Further work is already underway at ORAU to investigate the nature of the final product of "collagen" extraction and to improve the efficiency of the gelatinization and ultrafiltration procedures currently in use. 


\section{F Brock et al.}

\section{ACKNOWLEDGMENTS}

Many people from RLAHA past and present have contributed to helpful discussions about appropriate techniques to use for this study and the results generated, especially C Bronk Ramsey, REM Hedges, R Wood, P Ditchfield, J McCullagh, E Nitsch, and members of ORAU. J Southon, G Hodgins, and B Culleton also contributed to useful discussions, and the comments from 2 reviewers helped to improve on a previous version of this manuscript. The sample from Binchester was excavated by I Ferris, and the staff at Bowes Museum, Barnard Castle, County Durham, Durham County Council, and A Bayliss (English Heritage) are acknowledged for access to this bone for this study. $\mathrm{O}$ Acuto and his staff and students are thanked for training, access to laboratory facilities and providing consumables for SDS-PAGE analysis. A Crossley and C Johnston (Begbroke Nano, University of Oxford) provided valuable insight into analytical techniques, as well as allowing access to FTIR facilities and carrying out trial UV-Vis analysis. Amino acid analysis was undertaken by P Sharatt (PNAC, Dept. of Biochemistry, University of Cambridge), ICP-MS by S Strekopytor (NHM, London), and ion exchange chromatography by F Davies \& K Melvin (Dept. of Geography, University of Durham). FB and TH are very grateful to the Natural Environment Research Council of the UK (NERC) for their support of the NERC Radiocarbon Facility (NRCF).

\section{REFERENCES}

Ambrose SH. 1990. Preparation and characterization of bone and tooth collagen for isotopic analysis. Journal of Archaeological Science 17(4):431-51.

Arslanov KhA, Svezhentsev YuS. 1993. An improved method for radiocarbon dating fossil bones. Radiocarbon 35(3):387-91.

Beaumont W, Beverly R, Southon J, Taylor RE. 2010. Bone preparation at the KCCAMS laboratory. $\mathrm{Nu}$ clear Instruments and Methods in Physics Research B 268(7-8):906-9.

Brock F, Bronk Ramsey C, Higham T. 2007. Quality assurance of ultrafiltered bone dating. Radiocarbon 49(2):187-92.

Brock F, Higham T, Ditchfield P, Bronk Ramsey C. 2010. Current pretreatment methods for AMS radiocarbon dating at the Oxford Radiocarbon Accelerator Unit (ORAU). Radiocarbon 52(1):103-12.

Bronk Ramsey C, Pettitt PB, Hedges REM, Hodgins GWL, Owen DC. 2000. Radiocarbon dates from the Oxford AMS system: Archaeometry datelist 30. Archaeometry 42(2):459-79.

Bronk Ramsey C, Higham T, Bowles A, Hedges R. 2004. Improvements to the pretreatment of bone at Oxford. Radiocarbon 46(1):155-63.

Brown TA, Nelson DE, Vogel JS, Southon JR. 1988. Improved collagen extraction by modified Longin method. Radiocarbon 30(2):171-7.

Burba P, Shkinev V, Spivakov BY. 1995. On-line fractionation and characterization of aquatic humic substances by means of sequential-stage ultrafiltration. Fresenius' Journal of Analytical Chemistry 351(1): 74-82.

Burns DB, Zydney AL. 1999. Effect of solution pH on protein transport through ultrafiltration membranes. Biotechnology and Bioengineering 64(1):27-37.
Collins MJ, Riley MS, Child AM, Turner-Walker G. 1995. A basic mathematical simulation of the chemical degradation of ancient collagen. Journal of Archaeological Science 22(2):175-83.

Collins MJ, Nielsen-Marsh CM, Hiller J, Smith CI, Roberts JP, Progodich RV, Wess TJ, Csapò J, Millard AR, Turner-Walker G. 2002. The survival of organic matter in bone: a review. Archaeometry 44(3):383-94.

DeNiro MJ, Weiner S. 1988. Chemical, enzymatic and spectroscopic characterization of "collagen" and other organic fractions from prehistoric bones. Geochimica et Cosmochimica Acta 52(9):2197-206.

Di Lullo GA, Sweeney SM, Körkkö J, Ala-Kokko L, San Antonio JD. 2002. Mapping the ligand-binding sites and disease-associated mutations on the most abundant protein in the human, type I collagen. The Journal of Biological Chemistry 277(6):4223-31.

Dobberstein RC, Collins MJ, Craig OE, Taylor G, Penkman KEH, Ritz-Timme S. 2009. Archaeological collagen: Why worry about collagen diagenesis? Archaeological and Anthropological Sciences 1(1):3142.

Fernández J, Soria J, Viseras C. 1996. Stratigraphic architecture of the Neogene basins in the central sector of the Betic Cordillera (Spain): tectonic control and base-level changes. In: Friend PF, Dabrio CJ, editors. Tertiary Basins of Spain: The Stratigraphic Record of Crustal Kinematics. Cambridge: Cambridge University Press. p 353-65.

Fülöp RH, Rethmeyer J, Heinze S, König S. 2013. Why ultrafiltration is neither the problem nor the solution. Radiocarbon, these proceedings, doi:10.2458/ azu_js_rc.55.16296.

Furthmayr H, Timpl R. 1971. Characterization of collagen peptides by sodium dodecyl sulfate-polyacryla- 


\section{Bone “Collagen” Extraction Products for ${ }^{14} \mathrm{C}$ Dating}

mide electrophoresis. Analytical Biochemistry 41: 510-6.

Ghabbour EA, Davies G. 2009. Spectrophotometric analysis of fulvic acid solutions - a second look. Annals of Environmental Science 3:131-8.

Gillespie R. 1989. Fundamentals of bone degradation chemistry: collagen is not "the way." Radiocarbon 31(3):239-46.

Havers N, Burba P, Lambert J, Klockow D. 1998. Spectroscopic characterization of humic-like substances in airborne particulate matter. Journal of Atmospheric Chemistry 29:45-54.

Hedges REM, Law IA. 1989. The radiocarbon dating of bone. Applied Geochemistry 4:249-53.

Hedges REM, van Klinken GJ. 1992. A review of current approaches in the pretreatment of bone for radiocarbon dating by AMS. Radiocarbon 34(3):279-91.

Higham TFG, Jacobi RM, Bronk Ramsey C. 2006. AMS radiocarbon dating of ancient bone using ultrafiltration. Radiocarbon 48(2):179-95.

Hüls CM, Grootes PM, Nadeau M-J. 2009. Ultrafiltration: boon or bane? Radiocarbon 51(2):613-25.

Jacobi RM, Higham TFG, Bronk Ramsey C. 2006. AMS radiocarbon dating of Middle and Upper Palaeolithic bone in the British Isles: improved reliability using ultrafiltration. Journal of Quaternary Science 21(5): 557-73.

Jørkov MLS, Heinemeier J, Lynnerup N. 2007 Evaluating bone collagen extraction methods for stable isotope analysis in dietary studies. Journal of Archaeological Science 34(11):1824-9.

Longin R. 1971. New method of collagen extraction for radiocarbon dating. Nature 230(5291):241-2.

MacCarthy P, Rice JA. 1985. Spectroscopic methods (other than NMR) for determining functionality in humic substances. In: Aiken GR, MacCarthy P, McKnight DS, Wershaw RL, editors. Humic Substances in Soil, Sediment, and Water. Chichester: Wiley. p 45776.

Marshall PD, Meadows J, Bayliss A, Sparks R, Bronk Ramsey C, Beavan Athfield N. 2010. Scientific dating. In: Ferris I, editor. The Beautiful Rooms are Empty: excavations at Binchester Roman Fort, County Durham, 1976-1981 and 1986-1991. p 52738. Durham: Durham County Council.

Maspero F, Sala S, Fedi ME, Martini M, Papagni A.
2011. A new procedure for extraction of collagen from modern and archaeological bones for ${ }^{14} \mathrm{C}$ dating.Analytical and Bioanalytical Chemistry 401(6):2019-23.

Piez KA. 1984. Extracellular Matrix Biochemistry. New York: Elsevier.

Prigodich RV, Vesely MR. 1997. Characterization of the complex between bovine osteocalcin and type I collagen. Archives of Biochemistry and Biophysics 345: 339-41.

Semal P, Orban R. 1995. Collagen extraction from recent and fossil bones: quantitative and qualitative aspects. Journal of Archaeological Science 22(4):463-7.

Termine JD. 1984. The tissue-specific proteins of the bone matrix. In: Butler WT, editor. The Chemistry and Biology of Mineralized Tissues. Birmingham: Ebsco Media Inc. p 94-7.

van Klinken GJ. 1999. Bone collagen quality indicators for palaeodietary and radiocarbon measurements. Journal of Archaeological Science 26(6):687-95.

van Klinken GJ, Mook WG. 1990. Preparative high-performance liquid chromatographic separation of individual amino acids derived from fossil bone collagen. Radiocarbon 32(2):155-64.

Wilson J, van Doorn NL, Collins MJ. 2012. Assessing the extent of bone degradation using glutamine deamidation in collagen. Analytical Chemistry 84(21): 9041-8.

Wood RE, Barroso-Ruíz C, Caparrós M, Jordá Prado J, Galván Santos B, Davidson I, Higham TFG. 2013. Radiocarbon dating casts doubt on the late chronology of the Middle to Upper Palaeolithic transition in southern Iberia. Proceedings of the National Academy of Sciences of the USA 110(8):2781-6.

Yuan S, Wu X, Gao S, Wang J, Cai L, Liu K, Li K, Ma H. 2000. Comparison of different bone pretreatment methods for AMS ${ }^{14} \mathrm{C}$ dating. Nuclear Instruments and Methods in Physics Research B 172(1-4):424-7.

Yuan S, Wu X, Liu K, Guo Z, Cheng X, Pan Y, Wang J. 2007. Removal of contaminants from oracle bones during sample pretreatment. Radiocarbon 49(2):2116.

Zhang Z, Li G, Shi B. 2006. Physicochemical properties of collagen, gelatin and collagen hydrolysate derived from bovine limed split wastes. Journal of the Society of Leather Technologists and Chemists 90(1):23-8. 